Book Review Symposium "The portability of care in an increasingly mobile world: Chains, drains and circulation"

\title{
Introduction: The portability of care in an increasingly mobile world: Chains, drains and circulation
}

\author{
Sonia Parella \\ Universitat Autònoma de Barcelona. GEDIME/CER-Migracions \\ sonia.parella@uab.cat
}

\begin{abstract}
This symposium offers a critical discussion of the logics and dynamics behind the new 'care circulation' perspective offered by Loretta Baldassar and Laura Merla in their edited volume entitled "Transnational Families, Migration and the Circulation of Care: Understanding Mobility and Absence in Family Life". The different contributions to this symposium reflect in particular on the complementarities (or incompatibilities) between two visions of the mobilities of care: a 'care chains' approach located in a global economy perspective, and a multi-dimensional approach of the 'circulation of care' from a socio-anthropological perspective of family caregiving, located in kinship and the moral economies of care.

Keywords: gender; transnational family; migration; circulation of care
\end{abstract}

Resumen. Introducción. La transferencia del cuidado en un mundo cada vez más móvil: cadenas, fugas y circulación

Este simposio ofrece una discusión crítica de las lógicas y dinámicas en torno a la nueva perspectiva de la "circulación del cuidado» presentadas por Loretta Baldassar y Laura Merla en su volumen titulado Transnational Families, Migration and the Circulation of Care. Understanding Mobility and Absence in Family Life. En las distintas contribuciones del simposio se reflexiona en concreto, sobre las complementariedades (o incompatibilidades) entre dos visiones de las movilidades del cuidado: por un lado, la aproximación de las «cadenas de cuidado» basada en la perspectiva de la economía global y, por el otro, el enfoque multidimensional de la "circulación del cuidado", una perspectiva socioantropológica del cuidado emplazada en el parentesco y las economías morales del cuidado.

Palabras clave: género; familia transnacional; migración; circulación del cuidado 
The book "Transnational Families, Migration and the Circulation of Care" (2014, Routledge), edited by Loretta Baldassar and Laura Merla, is a wide-ranging and compelling study of migrant families coping with the practical and emotional difficulties of living and working across borders. The different contributions, which cover a rich array of ethnographic case studies, address the challenges of caring transnationally, based on a new theorization of transnational family solidarity through the lens of circulation.

Without denying the difficulties that confront migrants and their distant kin, the volume highlights the agency of family members in transnational processes of care in an effort to acknowledge transnational families as an increasingly common family form and to question the predominantly negative conceptualizations of this type of family. It offers a different, but complementary, perspective to the care chains framework which, in its classical version, is mainly based on the analysis of the commodification of care and of the mobility of care as a one-way traffic along a chain of women from the global south to the north.

Baldassar and Merla locate care within the economies of kinship, governed by 'generalized asymmetrical reciprocity' within transnational kinship networks. Care circulation is defined by the authors as "the reciprocal, multidirectional and asymmetrical exchange of care that fluctuates over the life course within transnational family networks subject to the political, economic, cultural and social contexts of both sending and receiving societies" (p. 22).

Thus, this approach focuses on the mobilities of care through a circulation (rather than a chain) metaphor, and offers a complementary perspective on the 'global care drain'. This concept was first used by Arlie Hochschild (2000), inspired by Rhacel Salazar Parrenas' (2000) earlier thesis, to refer to "a series of personal links between people across the globe based on the paid or unpaid work of caring" (2000:131). The 'chains' and 'care drain' metaphors exemplify the international division of reproductive labor and how gender inequalities are constitutive of patterns of globalization (Herrera, 2008). This frame is useful to highlight the connection between migrant care work and the privatization of social reproduction in a global market. Besides, according to Hassim (2008), not only do these 'care chains' illustrate how resources ('care' in this case) are distributed unequally around the world, but they also reveal the gendered (and racialized) nature of this inequality along a hierarchy of subordination and exploitation in which migrant female workers are located at the bottom (Parella, 2007; Fudge, 2013).

According to this feminist perspective, based on the economic notion of 'care drain' or 'care surplus', the commodification of care that alleviates the care crisis in the North creates a care crisis in the South (Yeates, 2005). Typically, care chains involve class-privileged women from rich countries who are unable to fulfill their 'domestic duties', and who manage the 'care crisis' by employing other women as domestic workers-- typically international migrants from poorer countries. These migrant women who have dependent children in their country of origin, in turn need substitute women to assume 
their own domestic duties. These 'other' women who are located at the end of the care chain are often unpaid family members, or low-paid substitute carers who will themselves need someone to care for their own children, adding a new link along the care chain. This suggestive literature points to the macro context that explains the global trade in domestic care services and the increasing demand for migrant domestic workers (Yeates, 2005). In sum, it is an effective approach for the analysis of social reproductive labor in a context of intensified globalization. But according to Escrivá (2005) and Herrera (2008), the 'care chain' framework is based on a dichotomous vision of reality grounded in Neo-marxist interpretations of how global relations of inequality are involved in the construction of these chains, and how gender inequalities related to the division of productive and reproductive work are constitutive of these dynamics. This dichotomous vision tends to disregard the internal mechanisms that create variations and complexity, which tends to create a vision of 'winners' only versus 'losers' only (Escrivá 2005).

By introducing the perspective, of 'circulation', Baldassar and Merla's new book contributes to reconceptualizing transnational processes, going beyond a focus on mother-child relationships to include multidirectional exchanges across generations and between genders, as well as incorporating all types of migratory flows (refugees, economic, professionals). It offers a more dynamic picture of the whole process that helps us stretch our understanding of the practices and processes that people use to manage their caregiving relationships across distance. As the authors state in the introduction of the book, "the perspective of care circulation ... is purposefully quite broad and 'flexible' and is meant to point to beliefs and practices about caring embedded in relationships wider than the nuclear family, which in turn are shaped and constrained by the broader (macro) social-structural context in transnational settings" (p. 22).

The main goal of this symposium is to reflect on the logics and dynamics behind the 'care circulation' perspective offered in this book, by considering the possible complementarities (or incompatibilities) between a 'care chains' approach of the mobilities of care from a global economy perspective (which stresses issues of care drain at a global level), and a 'care circulation', multidimensional approach from a socio-anthropological perspective of family caregiving, located in kinship and the moral economies of care.

This symposium provides an excellent opportunity for an in-depth discussion of different challenges, such as:

- The capacity of the 'care circulation' lens to take into account the diversity of actors involved (both providers and receivers, young and elderly, women and men, migrants and people 'left behind'), as well as the full range of social statuses and the variety of family situations and household types (married mothers with dependent children, professionals and highly skilled migrant workers, middle class migrants, etc.)

- The challenge of reconceptualizing the link between care, time and space in care and family studies, in the context of the 'mobility turn.' Certainly, 
'mobility' has accelerated over recent decades and challenges entire aspects of our social life (including, of course, 'care' practices and representations). Dissecting 'care' in this context of intensified 'circulation' and relationships across distance (due to geographical separations that are often not conceived as finite or sporadic), partially undermines the feminist representations of care as the management of everyday life associated with a common locus of residence.

- The relevance of moving beyond a focus on paid versus unpaid care provision and the emotional costs of care chains. This symposium offers the opportunity to examine the distinctive contributions or 'added value' of the care circulation perspective regarding different types of care work and the various dimensions that compose it. The 'care circulation' perspective could be a powerful analytical tool to comprehensively embrace the different aspects of care and the complexity of social interactions, including embodiment, emotions, the extension of body work (that is, all the physical tasks that are involved in domestic labor) and non-material (emotional) care work; with important variations depending on structures and cultural context.

- The potential and effectiveness of the 'care circulation' frame to capture power inequalities and issues of social justice in relation with the transnational transfer of care. In this sense, a close analysis of the set of for$\mathrm{mal} /$ informal and multidirectional arrangements that take place in these processes may reveal a wider range of key factors and bring nuances in our understanding of the various sources of inequality. Social differences and inequalities affect, according to the authors, "the shape, intensity and quality of participation of all the actors involved in (or excluded from) care circuits" (p. 55). In sum, the question is whether it becomes possible, through the 'care circulation' frame, to consider the dynamics of power as relational, and to draw attention to all the intersections that explain how different actors are embedded into the (gendered, racialized, class, age, life-course) hierarchies that sustain this circulation.

This symposium also stresses the implications of transnational care circulation for policymakers and, in particular, current understandings of 'social care' and their implications for social policies. The concept of 'social care' defines care as an activity and a set of relations lying at the intersection of the state, the market and the family and voluntary sector (Daly and Lewis, 2000:281). This conceptualization is a very good tool to overcome the analytical fragmentation of care. But it is based on notions of care and social rights that are anchored in a territorialized nation-state. The care circulation lens has the potential to extend the scope of care-related social policies and social citizenship beyond the limits of nation-states by bringing forward the transnational aspects of care, by taking into account the central notions of mobility, distance and geographical separation, and by constructing the implications of care-related transnational family arrangements as an object of social policy. 
Three leading experts accepted to contribute to this symposium by taking a critical look at the care circulation perspective. I thank Laura Oso Casas, Joan Tronto and Pierrette Hondagneu-Sotelo for taking the time to read the book and sharing their comments with us. In the last section of this symposium the authors of the book, Loretta Baldassar and Laura Merla, provide their own responses to the comments and suggestions offered by our three reviewers.

\section{Bibliographic references}

Baldassar, L; Merla, L. (eds.) (2014). Transnational Families, Migration and the Circulation of Care. Understanding Mobility and Absence in Family Life. New York and London: Routledge.

DaLY, M.; Lewis, J. (2000). "The concept of social care and the analysis of contemporary welfare states". British Journal of Sociology, 51 (2), 281-298. <http://dx.doi.org/10.1111/j.1468-4446.2000.00281.x>

EscrivÁ, A. (2005). "Aged Global Care Chains: a Southern-European Contribution to the Field", International Conference on Migration and Domestic Work in Global Perspective. Wassenaar (Netherlands), 26-29 May 2005.

FudGe, J. (2013). "Commodifying Care Work: Globalization, Gender and Labour Law". Paper presented at the Inaugural Labour Law Research Network Conference, Barcelona, June 13-15, 2013.

Hassim, S. (2008). "Global constraints on gender equality in care work". Politics and Society, 36 (3), 388-402. <http://dx.doi.org/10.1177/0032329208320568>

Herrera, G. (2008). "States, work and social reproduction through the lens of migrant experience: Ecuadorian domestic workers in Madrid". In: BABBER, I. and SiLver, R. (eds.). Beyond States and Markets: The Challenges of Social Reproduction. London: Routledge, 93-107.

Hochschild, A.R. (2000). "Global Care Chains and Emotional Surplus Value". In: Hutton, W. and Giddens, A. (eds.). On The Edge: Living with Global Capitalism. London: Jonathan Cape.

Parella, S. (2007). "Los vínculos afectivos y de cuidado en las familias transnacionales: Migrantes ecuatorianos y peruanos en España”. Migraciones Internacionales, 4 (2), 39-76.

Parreñas, RS. (2000). "Migrant Filipina Domestic Workers and the International Division of Reproductive Labor". Gender and Society, 14 (4), 560-580. <http://dx.doi.org/10.1177/089124300014004005>

Yeates, N. (2005). "A Global Political Economy of Care". Social Policy and Society, 4 (02), 227-234. $<$ http://dx.doi.org/10.1017/S1474746404002350> 